\title{
'And all of a sudden, it became my rescue': Language and agency in transnational families in Norway
}

\section{Maria Antonina Obojska ${ }^{\mathrm{a} *}$ and Judith Purkarthofer ${ }^{\mathrm{a}}$}

${ }^{a}$ MultiLing Center for Multilingualism in Society across the Lifespan, University of Oslo, Oslo, Norway

Postboks 1102 Blindern

0316 OSLO

$\underline{\text { m.a.obojska@iln.uio.no }}$

Maria Obojska holds an MA in Applied Linguistics (University of Warsaw) and works as a PhD Candidate at the Center for Multilingualism in Society across the Lifespan (University of Oslo). In her doctoral project she investigates language ideologies among Polish families in Norway. Her research interests include multilingualism, family language policy, and language ideologies among transnational adolescents.

Judith Purkarthofer received her PhD from the University of Vienna and works as a post-doctoral fellow at the Center for Multilingualism in Society across the Lifespan (University of Oslo). She is currently most interested in the construction of multilingual social spaces and language organization and does ethnographic and biographic research in families, schools and kindergartens. 


\title{
'And all of a sudden, it became my rescue': Language and agency in transnational families in Norway
}

\begin{abstract}
This article examines, how agency is constructed by members of two transnational families living in Norway in biographically oriented interviews. We understand agency as realised on the intertwined levels of grammar and meta-agentive discourse. Reports of speakers' lived language experience and their experiences with family language policies are analysed to demonstrate how speakers use different approaches to realise agency in their narratives. Drawing on data collected through Language Portraits and semi-structured interviews, we focus on how family members perceive and construct their agency when it comes to language learning, maintenance and management. ,
\end{abstract}

Keywords: agency, lived language experience, family language policy, Norway

\section{Introduction}

Recent sociolinguistic research has given considerable attention to multilingual transnational families (Curdt-Christiansen, 2013; King, Fogle, \& Logan-Terry, 2008; Lanza \& Li Wei, 2016; Smith-Christmas, 2015). The topic of agency in relation to language practice and management in these families has taken a prominent place in these discussions (Fogle \& King, 2013; Gyogi, 2015; Revis, 2016). Adding to the existing research, we examine discursive constructions of agency, i.e. the socioculturally-mediated capacity to act (Ahearn 2001, p. 112), by members of two multilingual, transnational families living in Norway. In line with Zhu Hua \& Li Wei (2016), we use the term 'transnational' rather than 'migrant' or 'expat' in order to stress the importance of the constant mobility and the cultural ties across and beyond national borders in the lives and experiences of our participants.

Increasing migration results in a growing diversity in migrant communities in Norway and in growing numbers of transnational families (cf. Statistics Norway, 2016). In this article we look at members of two such families - one of German and one of Polish origin. Polish and German transnationals are among the largest groups when it comes to work-driven migration to Norway - it 
is estimated that there are around 97200 Poles and 24600 German migrants living in Norway at the moment (Statistics Norway, 2018). We acknowledge that these statistics construct 'minorities' from individuals who come to Norway with a wide set of expectations and particular life stories and can hardly be regarded as uniform groups. Thus, we see the data discussed here rather as accounts of experiences made by members of transnational families more broadly and not as prototypical for families of German and Polish origin.

We draw on lived language experiences of speakers, composed of emotions, biographical encounters, language learning and use, and their aspirations and ideas about languages. Over time, these experiences form linguistic repertoires (Busch, 2012; Gumperz, 1964), including not only competencies, not neatly bounded languages as entities, but also all kinds of relations and knowledge, drawing on different forms of languages, speech styles, modes of expression, and the contexts of their use. The linguistic repertoire changes over the lifespan as it develops according to individuals' needs, ideas and possibilities of participation. Some forms of language gain more importance over time; some may be forgotten or even lost as they are not used any longer or are associated with negative social value.

Family Language Policy (FLP) research (King et al., 2008) deals with language use in family settings, aiming at understanding why and how language maintenance or shift happen in given circumstances. While earlier research highlighted parental perspectives, agency and decisions (Curdt-Christiansen, 2009; King \& Fogle, 2006; Kirsch, 2012), more recent work stresses children's ability to act and their agentive role in the establishment of language practices at home (e.g., Crump, 2017; Fogle \& King, 2013; Palviainen \& Boyd, 2013). Adding to this line of research, this article investigates how members of transnational families construct their own and other's agency in relation to language use and maintenance in stories recounted to researchers in interviews. We consider these constructions as specific strategies aimed at making sense of the family's language policy, an issue that is under discussion in most transnational families and poses specific challenges between personal expectations and public discourse in the wider society. As 
demonstrated by Purkarthofer \& Steien (2018), biographical narratives as a means of explanation and justification of FLPs are used by drawing on individual and societal experiences.

\section{Reported / Constructed Agency}

Agency has been defined by Ahearn (2001, p.112) as 'the socioculturally-mediated capacity to act'. We adopt this definition while at the same time acknowledging the processual character of negotiating agency through linguistic and non-linguistic means in interaction (cf. Al Zidjaly, 2009, p. 178). In line with Al Zidjaly, we see agency as inseparable from power, as the capacity to act lies at the core of the ability to exert power. We thus understand agency as a spectrum between powerless and empowered subject positions, and following De Fina (2003, p. 22), we specifically look at the represented degree of activity and initiative that the speakers claim for themselves or ascribe to others in their accounts.

Agency can be constructed by speakers in narratives on their language biographies, memories, and in their accounts of multilingual life worlds. It is constructed in retrospect when speakers look back on certain moments of their experiences, evaluating and highlighting specific events and, by framing them, achieve certain interactional goals, such as self-presentation. In this article, we are thus concerned with reported practices, and we look at agency as it is constructed in conversations with researchers through the use of linguistic and discursive means, employed to achieve, ascribe, assume and deny positions of power in narratives told by the participants.

Ricoeur (1995) emphasizes in his narrative theory that memories, and the stories about them, do not belong to only one person and that different stories are linked or entangled. According to Ricoeur (1995, p.6)

If each of us receives a certain narrative identity from the stories which are told to him or her, or from those that we tell about ourselves, this identity is mingled with that of others in such a way as to engender second order stories which are themselves intersections between numerous stories. Thus, the story of my life is a segment of the story of your life; of the story of my parents, of my friends, of my enemies, and of countless strangers. 
In relation to language, this means that families have a shared repertoire of stories around language experiences, which form the basis of family narratives. Parents and children draw on their individual and collective lived language experiences to make themselves and their actions understood by others. The resulting stories told, retold, and reinterpreted by the families and individual family members may contribute to the reification of certain language ideologies and language practices, thus contributing to the FLP of given families. Choosing certain stories over others and defining certain moments as decisive for the FLP is thus done by all family members and continues as long as the family stories persist. Ricoeur $(1995$, p. 8) phrases this as "tradition is transmission". Still, the stories are not translated directly into actions that influence the families' FLPs, but form instead an image of the FLP that encompasses beliefs and attitudes. Speakers describe and narrate their experiences, but they do so by extracting meaning and putting them in relation to other experiences. Schütz (1981[1924-28], p. 103) underlines that we do not memorize the events themselves, but it is their meaning that is re-evaluated when past experiences are retold. Narratives from language biographies are reconstructed in cooperation with other interactants, in our case with the researchers present, and they are constructed so that they carry meaning in the given interaction (Tophinke, 2002).

\section{Methodological framework: Language biographies and the construction of agency}

We make use of language biographies - the retelling of lived language experiences - to understand how agency is perceived and constructed in the context of FLP. The data were collected through Language Portraits (Busch, 2017) and semi-structured interviews with families, focusing on parents and older children. As a result of the task, speakers construct a multimodal image of their positions regarding language ideologies, learning experiences, experiences of migration, and also the individual and social influences in the repertoire (cf. Purkarthofer, 2017). Biographic data are subject to change over the lifespan and are always constructed in the interaction at a certain time and depend on the retrospective moment - in this article it is induced by the interview situation and 
the presence of the researcher. Biographical data are valuable, as it highlights speakers' intentions and experiences, data which are not accessible otherwise (Schütze, 1976).

As noted by Ahearn (2010), agency in language can be encoded in two ways: grammatically and through meta-agentive discourse, i.e. talk about one's own and others' actions, the attribution of responsibility for events and the representations of decision-making processes. In our understanding, these two levels are intertwined, as the use of linguistic means of encoding agency often serves the purpose of constructing agency in talk. Thus, in the analysis below, we consider the use of linguistic and grammatical means in the discursive representations of one's own and others' agency constructed by the participants in the interviews. When it comes to the grammatical encoding of agency, we focus in particular on the use of the following resources: syntactic functions and semantic roles (Ahearn, 2010; Duranti, 2006), pronominal choices (cf. De Fina, 2003), the use of reported speech (cf. De Fina, 2003; Lanza, 2012), as well as the use of active and passive voice. In our data, these choices have consequences for the construction of powerless and powerful subject positions in the meta-agentive talk of our participant, as they play a key role in acts of evaluations, in assuming and ascribing responsibility and in representing acts of initiative and choice in the participants' narratives.

The data for this article were collected in 2016 and are part of larger corpora. The first author, a Polish transnational, interviewed nine families of Polish origin living in Oslo area, while the second author, a German-speaking researcher from Austria, interviewed three families of German or German-Norwegian origin living in Oslo. The interviews were conducted by the researchers in Polish and German respectively, with one or several family members present. On the one hand, the shared linguistic and cultural background of the researchers and the interviewees facilitated the establishment of rapport during the interviews; on the other hand, it might have inspired the participants to bring to the fore the importance of respectively Polish and German and subdue the role other languages play in their lives. Nevertheless, despite using Polish and German primarily, the interactants infused their talk with Norwegian and English words. Such translingual 
practices are relatively typical for the multilingual life worlds of our participants, in which their mother tongue (Polish or German), the language of the host society (Norwegian) and other languages (mostly English) are of relevance. The original transcripts served as the basis for our analysis. We acknowledge that the encoding of agency may be language and/or culture-dependent, and thus not universal (see e.g., Fausey, Long, Inamori, \& Boroditsky, 2010). Nevertheless, our focus here lies not in pinpointing causal relationships between language, ethnicity and agency but rather in shedding light on the different ways our participants constructed agency in relation to language maintenance and use in the interview situation.

In this article we focus on two families who, on the one hand, share some characteristics and, on the other hand, can be viewed as relatively typical representatives of respectively German and Polish families in our dataset in terms of the migration trajectory and language practices. Both families consist of two adults and two children, neither of the families had an explicit plan to move to Norway and in both cases the migration was motivated by a job opportunity offered to one of the caregivers. Both families have been living in Norway for around 10 years and throughout this time have continued to use respectively German and Polish at home, putting high value on maintaining the mother tongue. At the same time, the families stress the importance of acquiring Norwegian by all family members as well as the children's learning additional foreign languages.

From the German-Norwegian data, we focus on the example of Eva, who moved to Norway for work 16 years ago. At the time of the interview Eva was living with her husband and two children in Oslo. The reason to focus on data from this family is that the family is well established in Norway with both parents holding qualified jobs and their network consisting of mostly Norwegian friends. Given the family's integration into Norwegian society, we would expect them to construct high levels of agency in their accounts of migration and language experiences. In addition to Norwegian friends and colleagues, the parents still maintain and seek friendship with other German transnationals and cherish the shared connection to Germany and/or the German language, which according to the participants facilitates mutual understanding of the migration 
experiences. The grandparents live in Germany and the family spends parts of their holidays there. The older child started in the Norwegian pre-school, but now attends a German-Norwegian bicultural school and the younger one started in a bicultural pre-school: for both children, German and Norwegian form part of their repertoire in school as well as in the family. Other languages are highly relevant for the parents (English, Italian but also Somali, Farsi and some others as they are used at the workplace). Eva's family, just like other families in the German corpus, defined work as an important factor influencing their move to Norway. Eva's family have been staying in Norway the longest and in this respect they differ from other German-Norwegian couples who move back to Germany after some years.

The Polish-Norwegian data analysed in this article were collected during two individual interviews with a mother and her 17 -year-old daughter. The data from this family were chosen as an example of how two generations of the same family can offer very different perspectives on family language policies. The daughter, Ana, was recruited by the first author through snowball sampling and later on provided contact with her mother, Nina. The women were interviewed separately due to conflicting schedules. Ana was interviewed at a coffee shop and Nina at the family's house. Nina has a degree in pedagogy but works in a service position at a hotel near Oslo, while Ana attends a private high school in the town where they live. At the time of the interviews, the women had been living in Norway for 10 years with their family (Nina's partner and their 10-year old son). The women's family is in many ways similar to the other families in the Polish corpus. The family followed a typical migration trajectory, in which the stepfather of Ana moved to Norway for work and the rest of the family followed after several years. The family maintains close transnational ties with friends and family in Poland, and the parents plan to move back to Poland upon retirement. Moreover, like all other families, the family uses primarily Polish at home but at the same time places high value on personal multilingualism. 


\section{German-Norwegian Data: "It really felt like my rescue"}

All German-Norwegian participants use several languages in their everyday life. In addition to German and Norwegian, they use English regularly and used at least one other language in the past (French, Spanish or Italian). The experiences of Norwegian, which will be in focus here, differ depending on the length of stay in Norway, the experiences of language learning and the attitudes towards one's own migration and life trajectory. In the interviews, knowledge of German is generally considered an advantage in learning Norwegian due to the close relation between the languages. Eva presents Norwegian, along with German and English, as the main languages in her life. She also mentions other languages she has learned (Spanish, Italian and Latin) and languages that are relevant for her work: Somali, Farsi, Pashto, Dari, Thai and French reach her through the medium of Norwegian as they are interpreted for her so that she can understand her clients.

All through the conversations (as can be seen in all excerpts), Eva has relatively long passages in which she expresses her thoughts and experiences while the interviewer merely provides back-channeling and affirmative interjections. Still, the interaction is shared between both participants, and the role of the interviewer as a foreigner working in Norway was without doubt important, especially in evaluating and sharing experiences as a member of a non-visible minority in Norway.

Eva had learned Norwegian as an exchange student, as she explains in Excerpt 1, years before her move to Norway "as a work migrant". At that time, she did not perceive it as relevant an impression that was supported by her feeling of not being completely satisfied with her exchange experience.

\section{Excerpt 1:}

Wir sind dann hierher=weil ich arbeitslos war in Deutschland und dann hab ich hier ne Arbeit gefunden, [mhm] also wir sind echte Arbeitsmigranten (lacht) $[\mathrm{mhm}]$ wir sind hierher gekommen, ich KONnte allerdings schon Norwegisch, weil ich AUStauschschülerin war $[o:: k]$ Ich=ich war 92/93 war ich mit [Organisation] hier Austauschschülerin (.) und konnte (.)

\section{Excerpt 1 [translated]:}

We then came here=because I was unemployed in Germany and then I found work here $[\mathrm{mhm}]$ so we are proper work migrants (laughs) $[\mathrm{mhm}]$ we came here, I already KNEW Norwegian because I had been EXChange student $[o:: k] \mathrm{I}=\mathrm{I}$ was in 92/93 I was with [organization] exchange student here (.) and knew (.) Norwegian rather fluently and then I applied for a position here [ $\mathrm{mhm}]$ 
Norwegisch eigentlich fließend und dann hab ich mich hier für ne Stelle beworben, [mhm] also in [Stadt] äh und hab die Stelle (.) obwohl ich Anfængerin war, bekommen=weil ich die Sprache konnte, [mhm, ja] was ja klar ist, weil da haben sich ganz viele Deutsche beworben [mhm] aber ich konnt halt die Sprache schon (.) [ja] Und æhm, (.) (.)æh, das war eigentlich lustig, weil ich IMMER gedacht hab, dass Norwegisch gelernt $\mathrm{zu}$ haben echt der größte Schmarrn war [mhm] (.)(.) also mir hats hier auch gar nicht so: gut gefallen. und plötzlich hatte ich das so als die Rettung für mich erwiesen, also es ist ja wirklich [mhm] als dieses Land so geBOOMT hat, und plötzlich gabs hier halt Arbeit, (.)und die Sprache hat mich wirklich gerettet. [mhm] Also deswegen, also ich hab auch ein ziemlich gutes Verhältnis zum Norwegischen, [mhm] weil ichs wirklich als so ne RETTung empfunden hab. actually in [town] äh and I got the position (.) even if I was a beginner=because I knew the language $[\mathrm{mhm}, \mathrm{ja}]$ what is clear, because a lot of Germans applied [mhm] but I already knew the language (.) [ja] And æhm, (.) (.)æh, that was rather funny, because I ALWAYS thought, learning Norwegian was the biggest nonsense [mhm] (.)(.) I did not like it that much here and all of a sudden, it became my rescue, as it was really $[\mathrm{mhm}]$ when this country was BOOMing and all of a sudden there was work, (.) and the language really saved me $[\mathrm{mhm}]$ That's why I have a quite good relationship to Norwegian [mhm] because it really felt like a RESCUE to me

One of the criteria that made Eva re-evaluate her stance towards Norwegian was the improved employability in Norway - a place she turned to while having difficulties finding work in Germany. In retrospect, she considers her knowledge of Norwegian as the main advantage vis-à-vis other applicants who were also applying from Germany and other countries.

To explain her relationship with languages, Eva repeatedly turns to memories and experiences - as for agency, she constructs herself as rather passive. In her words in Excerpt 1, she (and her husband) actively chose to migrate from Germany and this is expressed with personal pronouns and active voice. However, when she talks about language, she did not actively choose to learn Norwegian, instead through the means of the exchange, she became an experiencer of this new language. Only later, the language literally came to her rescue, which is a rather remarkable way of oppressing oneself as an actor. In contrast to other stories that focus on struggle and resistance (cf. Kramsch, 2009, Kristeva, 1988) towards a new language or environment, the process of integration is almost absent in this record. In her conclusion of this excerpt, she restates an 
affective evaluation of her good relationship with Norwegian, again personalizing the language and constructing it as an agent.

One possible explanation for the absence of explicitly stated agency in relation to the Norwegian language lies in her evaluation of her subject position in Norwegian society: later in the same interview, Eva speaks about her being perceived as passing as a Norwegian from her looks, but as being (or not being) othered in society when it comes to her language skills or accent.

Whereas Eva voiced her blending in as a member of society when it comes to her professional self (in Excerpt 1), she expresses a stronger interest in distinguishing herself (and her family) from families that she constructs as part of mainstream society. Still, in Excerpt 2 below, she talks about her everyday life, which she perceives as in many ways the same as others. There is, however, one thing, her having another language, which makes this family different from others. She expresses her feelings of happiness with her situation and contrasts them with a relatively regulated everyday life

\section{Excerpt 2:}

also wenn wir jetzt auch noch norweger wären, ich mein (.) was ja schon irgendwie cool ist daran, wenn man jetzt so mehr, also zum beispiel mehrere sprachen spricht oder mehrere, dass das ja schon zumindest total viele so weitere dimensionen eröffnet [...] aber ich find glaub ich eine sache, über die ich froh bin, also ich find manchmal so dieses leben mit familie mit kindern ist ja schon total genormt. also einfach dadurch, dass die kinder in bestimmten zusammenhängen sind, ist es also die leben ähneln sich wahnsinnig, also wenn die leute hier sitzen [in ihrer Arbeit] wir könnten auch ohne probleme platz tauschen oft. $[\mathrm{mhm}]$ und ich bin manchmal froh, dass es in meinem leben zumindest noch so ne (.) [mhm] komponente gibt, die ganz anders ist als die beiden. das ist irgendwie wichtig für mich, weil das ist schon so bißchen hart, so dieses absolute alle machen das selbe

\section{Excerpt 2 [translated]}

so if we were also Norwegians, I mean (.) what is somehow cool if one has more, if one speaks more languages for example or more, that this opens up so many more dimensions in a way [...] and I think that there is one thing, that I am happy about, sometimes I find this life with family, with children is completely in line [following a norm] simply because of the fact, that the children are in certain contexts. so the lives get incredibly alike, so when these people sit here [at my work place as a counselor] we could switch places without problems. [mhm] and I am sometimes happy, that $I$ have this other (.) $[\mathrm{mhm}]$ component in my life that is completely different than the two of them. that is somehow important for me, because it's hard this absolute 'all are doing the same thing" 
In Excerpt 2, Eva constructs the distinction from being 'different' or 'foreign', while she expresses a certain pressure to comply with the same norms and a certain lifestyle. This pressure is expressed through the factual presentation of reality ('das ist total genormt'), a strategy that erases agents from the phrase. She names languages as one component among other dimensions that serve to distinguish. But again, in her wording, she rather constructs the diverging language background of the family as a given, which plays out in a certain way, while she does not highlight her own contribution to 'making' this family life different from others.

Despite expectations about success stories that could be linked to this migration biography (given the knowledge of the country's language, the good education, the length of stay), we find the re-telling of lived language experiences to be focusing on events instead of actions. Eva openly speaks about her family's decision to move to Norway and takes an agentive position in this, but in other parts constructs her life (in Norway) as a series of events that happened to her without her taking a very active role. She expresses the wish to be more distinguishable at times from the majority of speakers. Eva's lack of explicitly constructed agency is interesting, especially when we think of Kristeva's (1988) image of the foreigner who is said to be the only one who has a biography and whose life consists of choices and not merely of events. Eva seems comfortable in her 'Norwegian self' (given her successful passing), but at the same time she misses her recognition as a foreigner and as different. As for family language policy, Eva interprets the family's German home language, the choice of schooling and other activities as rather conscious choices to enable her children to have a 'different' biography, one that is closer to hers and her husbands and not 'only' Norwegian, as she mentions in another sequence.

\section{Polish-Norwegian Data: tales of two generations}

All Polish-Norwegian participants use at least two languages in their everyday life. In addition to Polish and Norwegian, many use English regularly and used at least one other language in the past (e.g., Russian, French, Spanish). All families report Polish to be the main family language and, as will be seen below, the maintenance of Polish is considered important. 
The data presented here focus on the retrospective construction of agency of an immigrant child and her parents in interviews - by Ana, the child, who at the time of the interview was already a young woman, and by her mother, Nina. Ana and Nina reported Polish to be their main family language. Nevertheless, Norwegian and English are occasionally used in siblings' interactions, and in schoolwork-related conversations. Ana reported using Polish, Norwegian and English fluently and claimed some knowledge of German and Spanish. Nina reported speaking Polish fluently, and Norwegian and German at a 'good' level. She also claimed some knowledge of Russian and rudimentary competence in English.

In the following excerpts, Ana and Nina recall language management efforts aiming at the maintenance of Polish. In the first excerpt, Nina reports on the strategies employed by the parents.

\section{Excerpt 3}

Maria: A czyyyy coś robiliście takiego właśnie jak Ana była mała, albo teraz jak Kaj jest mały, żeby wspierać ten polski?

Nina: Oczywiście, oczywiście, że to robimy! Jak Ana była mała [...] zawsze, zawsze jak coś pisała, no nie wiem laurki powiedzmy jakieś takie rzeczy, zawsze jej mówiłam: „Aneczka tutaj np. ten błąd albo coś albo coś tutaj się tak nie pisze". No: no powiedzmy gramy w karty, wpisujemy [...] jakieś tam, no to wszystko jest robione polsku, no przecież nie po norwesku! Nie zapom[inamy] (.) nie no u nas w domu jest język polski, idziemy do sklepu też rozmawiamy po polsku. Nie zgrywamy sie, że jesteśmy Norwegami [...] Jesteśmy normalnie Polakami, którzy szanują polski, szanują polską tradycję koniec kropka.
Maria: And did you do something when Ana was little or do you do something now with Kaj to support their Polish? [...]

Nina: but of course, of course we do! When Ana was little[...] always, always when she wrote something, [...] I always told her: 'Aneczka, dear, here, for example there is a mistake' or 'this we don't write like that'. Well (.) let's say we play cards [...], we write something - everything is done in Polish, not in Norwegian, come on! We don't for[get]...no, at home there is Polish, when we go shopping we also speak Polish. We don't pretend to be Norwegians. [...] We simply are Poles, who respect the Polish language, respect the Polish tradition, full stop.

In the excerpt above, Nina constructs two levels of agency in relation to Polish maintenance: her individual agency regarding language policing at home and the collective (family) agency regarding implementing the policy of speaking Polish at home and outside when the family is together. These two levels are reflected by the pronominal switches in Nina's account - she oscillates between the grammatical first person singular and first person plural. Nina's own agency is underscored through the use of direct speech in narrating the gentle reprimands she gave her 
daughter when she made mistakes in Polish spelling. As noted by De Fina \& Georgakopoulou (2011), the characters who speak in the stories often also 'stand out' and actively take on specific roles in the storyworld. Thus, Nina casts herself in the role of language authority and 'language police' in the narrative. The collective family agency in relation to implementing the FLP is expressed by the use of verbs implying action: gramy ('we play'), wpisujemy ('we write'), idziemy ('we go'), nie zgrywamy się ('we don't pretend'). The collective agency is slightly diffused in Nina's account by the one off use of the passive voice: wszystko jest robione po polsku ('everything is done in Polish'). The explicit categorization of the family as 'Poles' can also be seen as an act of agency, as it is a declaration of pride and empowerment. On the whole, Nina presents both herself and her family as agents who purposefully strive to maintain Polish.

Ana's account constructs the parental strategies directed at language maintenance in a different way. In the excerpt below, prompted by the interviewer, Ana reflects on the language maintenance efforts undertaken by her parents after the move to Norway:

\section{Excerpt 4}

Maria: [...] A czy w jakikolwiek sposób, jak przyjechałaś do Norwegii, czy przypominasz sobie, że twoi rodzice, jakoś starali się, żebyś nie zapomniała polskiego, gdzieś cię wysyłali na jakieś kursy, albo kupowali ci książki albo coś takiego?

Ana: Nie (.) E:m mój tato[...] zawsze mi kupował książki, ale to dlatego, że ja lubię czytać. I on zawsze mi kupował książki, jak np. był w Polsce, to się pytał: "Ana, wysłać ci jakieś książki z Polski?", no i ja wtedy pisałam mu listę wielką i taka paczka do mnie przychodziła z książkami zawsze. Eeee i w tym sensie (.) no to mi się wydaje, że ja sama o to zadbałam, żeby zachowywać mój język. Tak samo, że ja mam kanał [na YouTube'ie] po polsku to mi też się wdaje że to jest właśnie podtrzymywanie tego języka $\mathrm{w}$ pewnym sensie.
Maria: [...] And when you came to Norway, do you remember your parents doing something so that you don't forget Polish? Did they send you to some courses somewhere or buy you books or something like that?

Ana: No (.) Um: my dad [...] always bought me_books but that was because I like reading a lot. So he always bought me books (.) when for instance he was in Poland then he would ask: 'Ana, should I send you some books from Poland?' and then I would make a huge list for him and then I would always get this package with books. Um: and in this sense (.) I think that I cared for it on my own to keep my language. It's the same with my [YouTube] channel in Polish, I also think that this is also keeping this language in some sense. 
In the excerpt above, Ana constructs her younger self as empowered to take responsibility for the maintenance of Polish. At the same time, she denies her parents' efforts using the negating particle nie in response to the interviewer's question and presents her father's initiative of buying Polish books as a response to her own wishes. Importantly, the direct speech ascribed to the father expresses an offer, which could be declined or accepted by Ana. Thus, the resulting action of buying Polish books is presented as dependent on the girl's decision, which again stresses her role and responsibility in language maintenance. Moreover, Ana constructs her own agency using verb phrases denoting action and initiative and positioning herself as the syntactic subject and semantic agent: pisałam mu liste ('I would make a list for him'), ja sama o to zadbałam ('I cared for it on my own'). She also takes responsibility for and ownership of the Polish language by explicitly referring to the language as her own - mój język ('my language') and stressing her own language maintenance strategies such as reading Polish books and keeping a Polish video-blog.

In the excerpts above, the mother and the daughter answer the researcher's questions on parental efforts aimed at language maintenance. The two resulting narratives differ significantly in terms of agency ascribed to the family members in the process of language maintenance. On the one hand, Nina ascribes initiative to herself in recounting how she corrected Ana's spelling mistakes and, on the other hand, she stresses the family's collective efforts to use Polish. In Ana's story, the collective agency of the family is virtually absent and the parental efforts are diminished. Instead, Ana constructs herself as the main agent responsible for her own language maintenance, both on the level of the story world and in the interview, by choosing to present this particular narrative to the researcher. These constructions, stressing their own initiatives in language maintenance, are consistent throughout the interviews with both mother and daughter.

\section{Discussion and Conclusions}

Family members in our data perceive and construct their agency in two ways with regard to language learning, maintenance and management. On the one hand, the participants assume the role of agents - both Nina and Ana construct themselves as actively caring for the Polish language. On 
the other hand, language becomes animated and is ascribed agency - the Norwegian language 'rescues' Eva and the use of the German language 'distinguishes' her and her family. In both case studies, the family members recount their own responsibility for the maintenance of family languages, but they are not the sole actors, i.e. the languages themselves are constructed as having agency. At the same time, choosing to present certain narratives but not others to the researcher, serves the discursive construction of agency in the interview situation.

In this paper, we combined the linguistic and discursive perspectives on agency (cf. Ahearn, 2010) to look at how our participants constructed their own and others' agency in interviews. Our participants employed diverse strategies to construct themselves and others on the continuum between agentive and passive (see also Lanza, 2012). On the one hand, they made use of syntactic functions, semantic roles, reported speech and the use of active vs. passive voice. In many cases, the use of these structures overlapped with the discursive construction of powerful (or powerless) subject positions - for example: Ana constructs herself as active and responsible in the language maintenance process through the consistent positioning of herself as a syntactic subject and semantic agent on the level of grammar; Eva constructs her own passivity through positioning herself as the semantic experiencer and patient. These choices present different degrees of responsibility for the events and decisions described in the accounts. Both Ana and Nina stress their own efforts to maintain Polish, while in Eva's account, the representations of her own initiatives and decisions with regard to language are absent, but agency is linked to the choices of employment and mobility. In these moments, we see how narratives are used to reinforce self-images of the speakers or interactional constructions with the researcher to foster the speakers' understanding of their experiences.

In our data set, the spectrum of agency is relational and (re)actional: it is expressed in (re)actions towards other animate and inanimate elements of the narratives. Thus Ana's agency is constructed in undertaking actions aimed at maintaining Polish. Nina constructs herself as an agent in relation to her children's language maintenance. Eva presents her family language as a means to 
establish distinction from the family's environment and to experience a different way of living. Having German in addition to Norwegian in their life in Norway is seen as an advantage. In another part of the data, the parents construct their choice of bilingual schooling as an action that was taken to support family values (openness and internationality) and in relation to the goals that speakers set for their FLP (i.e., not giving up on Polish/German in the family). Taking responsibility for one's own or one's child's learning is an important topic in FLP research: planning and acting on behalf of (imagined) FLPs plays an important part in family conversations (cf. Curdt-Christiansen, 2009). At the same time, there might be differences between the attitudes and plans and the enactment of the FLP in the family: we can thus assume that the FLP is influenced by representations of agency that we have presented here, but the biographical narratives do not give an exact account of the FLP. Ricoeur (1995, p. 8) claims that "tradition remains living, however, only if it continues to be held in an unbroken process of reinterpretation," and we read the accounts of lived language experiences and their use to interpret the families' language policies and decisions as part of the process of reinterpretations.

It is also worth noting how one's own vs. others' agency is differently recounted by our participants. It is particularly visible in Nina and Ana's narratives, an example of Ricoeur's "entangled stories" and a sort of memory-exchange retold in the family setting. While Nina stresses her own agency and actions undertaken in relation to language management by the whole family, in Ana's story parental actions are erased and her own are highlighted. These constructions might have been influenced by the participants' perceptions of the interviewer's expectations. They were aware that the researcher was interested in questions of language use by transnational Polish families and might have assumed that, being Polish herself, she welcomed reports on actions aimed at the maintenance of Polish. On the other hand, Ana's reported efforts resonate with the findings of the larger study (cf. Obojska, 2018), which showed that adolescent girls of Polish origin living in Norway tend to be interested and invested in maintaining their mother tongue, and often call on Polish national discourses to motivate their current and future language choices. 
We find that speakers recount changes in their linguistic repertoires as fortunate and challenging at the same time. Aspirations concern not only the 'complete (or satisfying) acquisition' of the language of the new country but also the maintenance of earlier languages, for example, the mother tongue. Aspirations related to maintaining the mother tongues are told with reference to different biographical experiences and obligations, as has been shown in another publication from the same corpus (Purkarthofer \& Steien, 2018). In our case, this can be seen when the German language in Eva's family becomes a desired marker of distinction which renders the family's life unique, while the maintenance of Polish in Nina and Ana's family becomes a matter of responsibility, duty and pride. The differing meanings which the participants attach to their languages may be reflective of the general discourses on mother tongues among German and Polish communities in Norway (cf. Obojska, 2018), a topic to be explored further in future studies At the same time, these representations point to the diversity of lived language experiences in transnational families in general, a factor that may be of pivotal importance for the development of particular family language policies and long-term also for language maintenance in transnational communities.

\section{Transcription conventions:}

here=beause immediate connection

[mhm] hearer signals, affirmative

(laughs) non-verbal utterance

EXchange emphasis

[Town] anonymization

(.) short pause

[...] deleted passage

Bold emphasis added by authors 
Acknowledgements: This work was supported by the Research Council of Norway through its Centers of Excellence funding scheme (project number 223265), and MultiFam (project number 240725).

\section{References}

Ahearn, L. M. (2001). Language and Agency. Annual Review of Anthropology, 30(1), 109-137.

Ahearn, L. M. (2010). Agency and language. In J. Jaspers, J.-O. Östman, \& J. Verschueren (Eds.), Handbook of Pragmatics Highlights (Vol. 7, pp. 28-48). Amsterdam: John Benjamins Publishing Company.

Al Zidjaly, N. (2009). Agency as an interactive achievement. Language in Society, 38(2), 177-200.

Busch, B. (2012). The linguistic repertoire revisited. Applied Linguistics, 33, 503-523.

Busch, B. (2017). Expanding the Notion of the Linguistic Repertoire: On the Concept of Spracherleben - The Lived Experience of Language. Applied Linguistics, 38(3), 340-358.

Curdt-Christiansen, X. L. (2009). Invisible and visible language planning: ideological factors in the family language policy of Chinese immigrant families in Quebec. Language Policy, 8(4), $351-375$.

Curdt-Christiansen, X. L. (2013). Negotiating Family Language Policy: Doing Homework. In M.

Schwartz \& A. Verschik (Eds.), Successful Family Language Policy (pp. 277-295). Springer Netherlands.

Crump, A. (2017). "I speak all of the language!”: Engaging in family language policy research with multilingual children in Montreal. In J. Macalister \& S. H. Mirvahedi (Eds.), Family language policies in a multilingual world: Opportunities, challenges, and consequences (pp. 154-174). London: Routledge.

De Fina, A. (2003). Identity in Narrative: A study of immigrant discourse (Vol. 3). Amsterdam: John Benjamins Publishing Company.

De Fina, A., \& Georgakopoulou, A. (2011). Analyzing Narrative: Discourse and Sociolinguistic Perspectives. Cambridge University Press. 
Duranti, A. (2006). Agency in Language. In Duranti, A. (Ed.), A Companion to Linguistic Anthropology. Blackwell Publishing Ltd.

Fausey, C. M., Long, B. L., Inamori, A., \& Boroditsky, L. (2010). Constructing Agency: The Role of Language. Frontiers in Psychology, 1.

Fogle, L. W., \& King, K. A. (2013). Child Agency and Language Policy in Transnational Families. Issues in Applied Linguistics, 19(0).

Gyogi, E. (2015). Children's agency in language choice: a case study of two Japanese-English bilingual children in London. International Journal of Bilingual Education and Bilingualism, 18(6), 749-764.

Gumperz, J. J. (1964). Linguistic and social interaction in two communities. American Anthropologist, 66/6, 137-153.

King, K. A. (2016). Language policy, multilingual encounters, and transnational families. Journal of Multilingual and Multicultural Development, 37(7), 726-733.

King, K. A., Fogle, L., \& Logan-Terry, A. (2008). Family Language Policy. Language and Linguistics Compass, 2(5), 907-922.

King, K., \& Fogle, L. (2006). Bilingual parenting as good parenting: Parents’ perspectives on family language policy for additive bilingualism. International Journal of Bilingual Education and Bilingualism, 9(6), 695-712.

Kirsch, C. (2012). Ideologies, struggles and contradictions: an account of mothers raising their children bilingually in Luxembourgish and English in Great Britain. International Journal of Bilingual Education and Bilingualism, 15(1), 95-112.

Kramsch, C. (2009). The Multilingual Subject. Oxford: Oxford University Press.

Kristeva, J. (1988). Etranger à nous-même. Paris: Fayard. 
Lanza, E. (2012). Empowering a migrant identity: agency in narratives of a work experience in Norway. Sociolinguistic Studies. 6(2), 285-307.

Lanza, E., \& Li Wei. (2016). Multilingual encounters in transcultural families. Journal of Multilingual and Multicultural Development, 37(7), 653-654.

Obojska, M. (2018). Between duty and neglect: Language ideologies and stancetaking among Polish adolescents in Norway. Lingua. https://doi.org/10.1016/j.lingua.2018.03.009

Palviainen, Å., \& Boyd, S. (2013). Unity in Discourse, Diversity in Practice: The One Person One Language Policy in Bilingual Families. In M. Schwartz \& A. Verschik (Eds.), Successful Family Language Policy (pp. 223-248). Springer Netherlands.

Pedersen, S. V.. (2013). Utvandring fra Norge 1971-2011. Rapporter 30/2013. Statistisk sentralbyrå. $\quad$ Retrieved from https://www.ssb.no/en/befolkning/artikler-ogpublikasjoner/utvandring-fra-norge-1971-2011

Purkarthofer, J. \& Steien, G. B. (in press). "Comme si on connaît pas une autre langue que le swahili": Multilingual parents in Norway on change and continuity in their family language policies. International Journal of the Sociology of Language.

Purkarthofer, J. (2017). Building expectations: Imagining family languages policy and heteroglossic social spaces. International Journal of Bilingualism. doi:10.1177/1367006916684921

Revis, M. (2016). A Bourdieusian perspective on child agency in family language policy. International Journal of Bilingual Education and Bilingualism, O(0), 1-15.

Ricoeur, P. (1992). Oneself as Another. Chicago: University of Chicago Press.

Ricoeur, P. (1995). Reflections on a new ethos for Europe. Philosophy \& Social Criticism 21(5/6). $3-13$.

Schütz, A. (1981[1924-1928]). Theorie der Lebensformen. Frankfurt/Main: sSuhrkamp.

Schütze, Fritz (1976). Zur soziologischen und linguistischen Analyse von Erzählungen. Internationales Jahrbuch für Wissens- und Religionssoziologie. 7-41. 
Smith-Christmas, C. (2015). Family Language Policy: Maintaining an Endangered Language in the Home. Springer.

Statistics Norway. (2016). More family reunifications than new marriages. Retrieved July 28, 2016, from http://www.ssb.no/en/befolkning/artikler-og-publikasjoner/more-family-reunificationsthan-new-marriages

Statistics Norway. (2018). Immigrants and Norwegian-born to immigrant parents, foreign-born and foreign citizens, by country background, by country of birth and citizenship.. Retrieved April 16, 2018, from https://www.ssb.no/304491/immigrants-and-norwegian-born-toimmigrant-parents.1-january-sy-92

Tophinke, D. (2002). Lebensgeschichte und Sprache. Zum Konzept der Sprachbiografie aus linguistischer Sicht. In Adamzik, K. \& Roos, E.(Eds.), Biografie linguistiche. Bulletin valsasla 76, Université de Neuchâtel, 1-14.

Zhu Hua, \& Li Wei (2016). Transnational experience, aspiration and family language policy. Journal of Multilingual and Multicultural Development, 37(7), 655-666. 